OPEN ACCESS

Edited by:

Cheryl J. Craig,

Texas A\&M University, United States

Reviewed by:

Balwant Singh,

Partap College of Education, India

Nathalie Sandra Reid,

University of Regina, Canada

*Correspondence:

Ineke M. Pit-ten Cate

ineke.pit@uni.lu

tORCID:

Ineke M. Pit-ten Cate orcid.org/000-0002-9847-9683

Salvador Rivas

orcid.org/0000-0002-1496-6004

Specialty section: This article was submitted to

Teacher Education, a section of the journal

Frontiers in Education

Received: 24 March 2021 Accepted: 26 April 2021

Published: 11 May 2021

Citation:

Pit-ten Cate IM, Rivas S and Busana G (2021) Increasing the Diversity of the

Teacher Workforce: Socio-Political Challenges to Reducing Inequalities in

Access to Teacher

Education Programs.

Front. Educ. 6:685113.

doi: 10.3389/feduc.2021.685113

\section{Increasing the Diversity of the Teacher Workforce: Socio-Political Challenges to Reducing Inequalities in Access to Teacher Education Programs}

\author{
Ineke M. Pit-ten Cate ${ }^{1 * \dagger}$, Salvador Rivas ${ }^{1 \dagger}$ and Gilbert Busana ${ }^{2}$ \\ ${ }^{1}$ Luxembourg Centre for Educational Testing (LUCET), Faculty of Human Sciences, Educational Sciences and Social Sciences, \\ University of Luxembourg, Esch-sur-Alzette, Luxembourg, ${ }^{2}$ Department of Education and Social Work, Faculty of Human \\ Sciences, Educational Sciences and Social Sciences, University of Luxembourg, Esch-sur-Alzette, Luxembourg
}

Cross-border migration leads to a diversification of societies, which is reflected in the education system, where classrooms are composed of students with heterogeneous cultural, linguistic, socio-economic characteristics. However, this diversity is only to a limited extent reflected in the teacher population, even though teachers from different backgrounds can bring specific intercultural competencies, have more positive attitudes toward multicultural heterogeneity and act as role models. To facilitate the diversification of the teaching profession, it is imperative that the cohorts of students entering teacher education programs represent the diversity of societies, however studies have shown students with migration backgrounds or from families with lower socio-economic status are underrepresented in such programs. This study considered the demographic constellation of applicants for admission into the teacher education program in Luxembourg (2015-2019) and investigated to what extent the admission process (dis) advantages certain groups. Results revealed that although applicants come from diverse backgrounds, proficiency in the country's native languages poses a disadvantage for students with migration backgrounds. In addition, applicants coming from more privileged families stand a better chance of being admitted. Results are interpreted within the framework of social mobility and social reproduction. Implications for the admission to the teachers' education program are discussed.

Keywords: diversity, teacher training, student selection, social mobility, social reproduction, higher education

\section{INTRODUCTION}

In both Europe and the United States, increased levels of cross-border migration have resulted in the diversification of classroom compositions, and students with a variety of cultural, ethnic, linguistic and socio-economic characteristics attend the majority educational settings. Such student diversity is however only to a limited extent reflected in the teaching profession. One reason may be that students with migration backgrounds or students from less privileged families generally experience educational disadvantages, reflected in lower academic achievement outcomes (OECD, 2016) and less participation in more demanding secondary or tertiary educational tracks (Baumert and Schümer, 2002; Oakes, 2005; Waters et al., 2013). In most countries, teacher education programs are offered at university or college level, hence the under-representation of students 
with migration backgrounds in higher educational tracks almost automatically leads to an over-representation of the countries' majority group in the teaching profession. For reasons that we note below it is worthwhile to recruit more people with migration backgrounds into teacher education programs and subsequently into the education system. Teachers with migration backgrounds ${ }^{1}$ can bring specific intercultural competencies which enable them to deal successfully with the increasing heterogeneity of students in classrooms and schools (Hachfeld et al., 2012). Based on their own experiences, they may be more aware of educational disadvantages related to student background characteristics and hence more motivated to overcome such inequalities and act as positive role models (Su, 1997; Magaldi et al., 2018). This notion is supported by findings that -compared to teachers from the majority group- teachers with migration backgrounds have higher multicultural beliefs (Hachfeld et al., 2012) and are guided more often by multicultural attitudes when teaching (Kelle and Kluge, 2010). It is therefore not surprising that many countries try to recruit students with migration backgrounds into their teaching education programs (e.g., Ingersoll and May 2011; Rotter, 2012) in an attempt to diversify the teacher workforce. However, students with migration backgrounds are still largely outnumbered by students from majority groups in universities at large and in teacher education programs in particular (Ingersoll and May 2011; Edelmann, 2013). This under-representation of students with migration backgrounds may reflect educational disadvantages associated with practices within educational structures (e.g., Boudon, 1974; Hillmert, 2013). These educational disadvantages may be most pronounced for $1^{\text {st }}$ and $2^{\text {nd }}$ immigrant generations but should reduce over time due to positive assimilation and acculturation processes, as families with migration backgrounds increasingly integrate in the host society. Indeed, social mobility patterns indicate that $2^{\text {nd }}$ and later generation students may advance beyond their parents (Azzolini and Barone, 2013; Alba and Foner, 2016).

Although general patterns of social mobility have been studied for many decades, with several studies focusing on educational outcomes of different generations of immigrants (Fine-Davis and Faas, 2014; Luthra and Soehl, 2015; Alba and Foner, 2016), less is known about these trends within the teaching profession. As diversity in the professional workforce is to a large extent determined by the diversity in cohorts of pre-service teachers, this paper focuses on demographic constellations of student cohorts within a teacher education program. The study was conducted in Luxembourg, a country characterized by cultural, linguistic and ethnic diversity, with approximately $43 \%$ of students in the education system having a migration background (Lenz and Heinz, 2018). At the moment, this student diversity is not reflected in the teacher population,

\footnotetext{
${ }^{1}$ Migration background is defined in accordance with the European Framework (United Nations Economic Comission for Europe, 2006). That is, a migrant is defined as a person who is foreign born or a descendant of foreign born (grand) parents. More specifically, people with migration backgrounds may have moved to the host nation ( $1^{\text {st }}$ generation) or have at least one parent who previously moved to the host country ( $2^{\text {nd }}$ generation).
}

with data from the labor force study showing that $85 \%$ and $75 \%$ of teachers in primary and secondary education respectively, have the Luxembourgish nationality (Institut national de la statistique et des études économiques du Grand-Duché de Luxembourg, personal communication, September 8, 2020). In the last few years, there has been a high demand for teachers, but at the same time there are strict criteria for entry into the teacher education program (e.g., students must be competent in three languages: Luxembourgish, French and German, as well as proficient in Mathematics and Science). This may put applicants with migration backgrounds at a disadvantage for acceptance into the teacher education program and, in turn, contributes to the continued disparity between the heterogeneity in student population and the teachers' work force.

\section{THEORETICAL BACKGROUND}

Educational disadvantages for students with migration backgrounds have been well-documented (e.g., Van de Werfhorst and Mijs, 2010; OECD, 2018). Students with migration backgrounds generally reach lower academic standards than students of the majority group and therefore have fewer career opportunities (Schalke et al., 2013), which in turn leads to the reproduction of social inequality (i.e., second and later generations of immigrants not reaching beyond the often low educational attainment or low status occupations of their parents) rather than create opportunities for social mobility (i.e., the intergenerational movement between levels of educational attainment, occupations, socio-economic status or social classes; Morgan, 2006). One approach to overcome social inequality in education is to prepare teachers to accommodate an increasingly diverse student population (Hachfeld et al., 2015), for example by incorporating multiculturalism in educational curricula as well as by changing teachers' beliefs and attitudes concerning diversity (Banks, 2004; Hachfeld et al., 2015). Another approach focuses on diversifying the teacher population. In this context, many countries strive to diversify their teacher work force (Rotter, 2012), with the idea that teachers with migration backgrounds bring specific intercultural competencies and can better motivate students with migration backgrounds and act as positive role models (Akbaba et al., 2013; Magaldi et al., 2018). To reach the goal of diversifying the teacher work force, the cohorts of students in teacher education programs should increasingly reflect societal diversity. However, research has indicated that universities, and teacher education programs in particular, are still characterized by an over-representation of students of the majority group in society and under-representation of students with migration backgrounds (Edelmann, 2013).

Although such under-representation may reflect interindividual differences in academic achievement, it is also likely that certain practices within the educational structures provide (dis)advantages for certain groups of students (Boudon, 1974; Hillmert, 2013). Educational inequalities may reflect certain national policies that are historically and culturally embedded and may -unintentionallycreate (dis)advantages for certain groups of students (Apple, 2001). More specifically, educational inequalities may result from societal 
and institutional structures and conditions (e.g., secondary school tracking; access opportunities for tertiary education) which create (dis)advantages in educational opportunities and attainment for students, for example in relation to their socio-economic status or migration backgrounds (Hadjar and Gross, 2016). Boudon (1974) distinguished between primary and secondary effects to explain social inequalities. Primary effects reflect differences in academic achievement between students with and without migration backgrounds which may be related to language, especially when the home language has evolved differently than the school language. Secondary effects relate to practices within the educational system which result in disadvantages for different groups of students. For example, results of studies in countries in which students are assigned to different secondary school tracks have repeatedly shown that students with a migration background have a lower chance of being promoted to the highest academic track even after controlling for academic achievement (e.g., OECD, 2010; Geven et al., 2018). Participation in lower secondary tracks will have long lasting effects as it reduces the students' learning opportunities and will prevent them from applying for or attending higher levels of tertiary education (university level). Together, primary and secondary effects may therefore determine future prospects of these students and the extent to which they are able to successfully integrate in the host society. There is ample research on different factors that may explain educational disadvantages of students with migration backgrounds. In addition, in the last three decades studies have appeared looking into experiences of teachers with migration backgrounds (e.g., Georgi, 2013; Bressler and Rotter, 2017). However only a few studies (e.g., Döll and Knappik, 2015) have considered how certain educational practices, such as a primary focus on native language proficiency, may enhance or reduce possible biases against students with migration backgrounds. Such studies are important as they help us identify institutional factors that may explain why people with migration backgrounds continue to be under-represented in the teaching profession. In the current study, we therefore investigate to what extent the selection process for admission to the teacher education program at the University of Luxembourg may give an advantage to applicants of the majority group. We are specifically interested in the stability of the socio-demographic constellation of the cohort of applicants in comparison to the cohort of admitted students. Finally, we will investigate to what extent socio-demographic data of applicants and admitted students suggests social mobility or rather reflects a replication of social inequality.

\section{LUXEMBOURG CONTEXT}

The education system in Luxembourg is characterized by a diverse student population in terms of their socio-economic, linguistic or migration backgrounds (Lenz and Heinz, 2018). This diversity reflects migration of families from other European countries to Luxembourg at specific socio-historical moments (Massey et al., 1998), most notably Italian families at the height of the steel industry, families from former Yugoslavia fleeing the war and Portuguese families to meet construction and service industry needs. Migration accounts for the majority of
Luxembourg's population growth and currently only 53\% of the population holds the Luxembourgish nationality (STATEC, 2020a). Most migrants enter the country for work (STATEC, 2020b), however despite the economic opportunities for these families, large scale studies have repeatedly indicated educational inequalities (e.g., Boehm et al., 2016; Fischbach et al., 2016; OECD, 2016). More specifically, students with migration backgrounds attain lower learning outcomes and are underrepresented in higher educational tracks (Hadjar et al., 2018; Lenz and Heinz, 2018; OECD, 2019). Such inequalities have long lasting effects as they impact students' future career prospects and general well-being (Schalke et al., 2013).

Although the student population is very diverse, this is not reflected in the teaching profession. This may be partly due to specific requirements and selection criteria, whereby especially the strong focus on native languages in both admission to teacher education program and later entry into the teaching profession tend to favor people from the majority group. For example, the Luxembourgish law governing admission to the teaching profession stipulates that one must be an EU National and master the three official languages of the country (Ministère d État, 2020). To enter the teaching profession, it is required to complete a Bachelor of Education. Candidates can register for the program offered by the University of Luxembourg when holding a secondary school leaving diploma from a Luxembourgish school or a recognized diploma from a foreign country. Since 2011, all eligible candidates have to take a competitive entry examination to demonstrate their competencies in mathematics and sciences as well as in reading comprehension in the three official national languages - French, German and Luxembourgish - and grammar in the first two (Busana, et al., in press; European Commission, EACEA and Eurydice, 2018a; Eurybase, 2010; University of Luxembourg, 2020a). After completing a Bachelor of Education in Luxembourg or at another recognized institution, newly qualified teachers need to pass competitive tests set by the Ministry of Education, which assess candidates' knowledge of the three official national languages, plus knowledge of Luxembourgish school legislation and regulation as well as pedagogical and didactical skills (i.e., planning of a learning situation; the methodology and didactics concerning the primary school curriculum; and Luxembourgish culture). Their results are then used to determine the candidates' rank order of entering the teaching profession (Eurybase, 2010).

Currently there is a shortage of teachers in Luxembourg. This means that -providing they pass the tests set by the Ministry of Education-, candidates completing a Bachelor of Education degree have a high chance of finding a position. Therefore, the diversity of cohorts that are admitted into the teacher education program will to large extent determine the diversity of teachers in the future.

\section{CURRENT STUDY}

The current study investigates the diversity of candidates registering for the Bachelor of Education program at the University of Luxembourg in relation to the constellation of cohorts that were admitted to the program. Data will be presented for five cohorts of 
TABLE 1 | Demographic characteristics of candidates registering for the entree exam per year (2015-2019) . $^{2}$

\begin{tabular}{|c|c|c|c|c|c|}
\hline & 2015 & 2016 & 2017 & 2018 & 2019 \\
\hline & $N=285$ & $N=285$ & $N=257$ & $N=309$ & $N=306$ \\
\hline \multicolumn{6}{|l|}{ Gender } \\
\hline Male & $23.5 \%$ & $28.8 \%$ & $19.8 \%$ & $28.5 \%$ & $31.0 \%$ \\
\hline Female & $76.5 \%$ & $71.2 \%$ & $80.2 \%$ & $71.5 \%$ & $69.0 \%$ \\
\hline \multicolumn{6}{|l|}{ Migration background indicators } \\
\hline \multicolumn{6}{|l|}{ Country of birth } \\
\hline Luxembourg & $92.5 \%$ & $93.6 \%$ & $95.3 \%$ & $93.1 \%$ & $92.1 \%$ \\
\hline Elsewhere in Europe & $2.9 \%$ & $2.1 \%$ & $3.5 \%$ & $4.0 \%$ & $4.6 \%$ \\
\hline Balkan & $1.4 \%$ & $2.5 \%$ & $0.0 \%$ & $1.0 \%$ & $1.3 \%$ \\
\hline Elsewhere outside Europe & $3.2 \%$ & $1.8 \%$ & $1.2 \%$ & $2.0 \%$ & $2.0 \%$ \\
\hline \multicolumn{6}{|l|}{ Language spoken at home } \\
\hline Luxembourgish & $77.9 \%$ & $78.6 \%$ & $68.1 \%$ & $60.8 \%$ & $68.6 \%$ \\
\hline Luxembourgish bilingual & $2.1 \%$ & $1.4 \%$ & $1.6 \%$ & $2.3 \%$ & $2.3 \%$ \\
\hline Other European language & $14.7 \%$ & $15.4 \%$ & $24.5 \%$ & $26.5 \%$ & $23.9 \%$ \\
\hline Balkan language & $3.5 \%$ & $3.5 \%$ & $4.7 \%$ & $8.7 \%$ & $4.9 \%$ \\
\hline Other non-European language & $1.8 \%$ & $1.1 \%$ & $1.2 \%$ & $1.6 \%$ & $0.3 \%$ \\
\hline \multicolumn{6}{|l|}{ Socio-economic indicators } \\
\hline \multicolumn{6}{|l|}{ Highest parental education } \\
\hline Secondary education only & $34.5 \%$ & $41.4 \%$ & $48.2 \%$ & $50.0 \%$ & $44.1 \%$ \\
\hline Vocational/crafts certificate & $18.3 \%$ & $17.9 \%$ & $15.3 \%$ & $17.5 \%$ & $14.4 \%$ \\
\hline Professional/technical diploma & $27.8 \%$ & $18.6 \%$ & $18.0 \%$ & $14.9 \%$ & $22.2 \%$ \\
\hline University degree (+PhD) & $19.4 \%$ & $22.1 \%$ & $18.4 \%$ & $17.5 \%$ & $19.3 \%$ \\
\hline \multicolumn{6}{|l|}{ Highest parental occupation } \\
\hline Manager & $10.9 \%$ & $12.3 \%$ & $10.9 \%$ & $15.2 \%$ & $11.8 \%$ \\
\hline Professional & $55.4 \%$ & $46.0 \%$ & $42.8 \%$ & $35.6 \%$ & $41.8 \%$ \\
\hline Mechanic & $3.5 \%$ & $6.3 \%$ & $9.7 \%$ & $7.1 \%$ & $9.5 \%$ \\
\hline Clerical support worker & $11.9 \%$ & $14.0 \%$ & $10.1 \%$ & $10.0 \%$ & $12.1 \%$ \\
\hline Services and sales & $4.6 \%$ & $6.7 \%$ & $6.6 \%$ & $6.5 \%$ & $7.2 \%$ \\
\hline Skilled agricultural, forest and fish workers & $0.7 \%$ & $0.7 \%$ & $0.8 \%$ & $0.0 \%$ & $0.3 \%$ \\
\hline Craft and related trade workers & $7.4 \%$ & $8.8 \%$ & $11.3 \%$ & $17.2 \%$ & $14.4 \%$ \\
\hline Plant and machine operators & $2.5 \%$ & $2.5 \%$ & $3.5 \%$ & $6.5 \%$ & $1.6 \%$ \\
\hline Elementary occupations & $2.1 \%$ & $0.7 \%$ & $3.1 \%$ & $1.3 \%$ & $0.7 \%$ \\
\hline Unemployed/Retired & $1.1 \%$ & $2.1 \%$ & $1.2 \%$ & $0.6 \%$ & $0.7 \%$ \\
\hline \multicolumn{6}{|l|}{ Highest parental occupation } \\
\hline Unskilled & $29.4 \%$ & $34.1 \%$ & $35.8 \%$ & $41.7 \%$ & $36.5 \%$ \\
\hline Skilled & $70.6 \%$ & $65.9 \%$ & $64.2 \%$ & $58.3 \%$ & $63.5 \%$ \\
\hline
\end{tabular}

${ }^{a}$ Applicants that were included more than once in the dataset due to re-registrations after unsuccessful applications (N =228), were only considered the first time they appeared.

applicants and analyzed to assess the extent to which their sociodemographic background is associated with their chances of being admitted to the teaching education program.

\section{ETHICAL CONSIDERATIONS}

Guidelines of the University's ethical review panel were followed at all times. The study is based on secondary data analysis. The data used in the study was collected via questionnaire as part of the application process. Applicants gave informed consent that their data could be used for administrative, quality assurance and monitoring purposes. We worked with a fully anonymized data set, whereby we only conducted group level analyses, rather than focus on individuals.

\section{METHODS}

The current study reflects secondary data analysis of five cohorts of applicants (2015-2019) into the teachers' education program at the University of Luxembourg. Socio-demographic data was collected as part of the program's registration and quality assurance process, but is not used for admission decision purposes. Data includes information on candidates' age, gender, nationality and first language as well as their parent's educational attainment and current occupation. The data were collected via online questionnaire (University of Luxembourg, 2020b).

\section{RESULTS}

A summary of socio-demographic data for applicants in the years 2015-2019 is provided in Table 1. The gender of the applicants was relatively stable and reflective of the gender imbalance in the teachers' profession, especially in primary education $(69-80 \%$ female applicants). Data for the country of birth shows that most applicants $(90+\%)$ were born in Luxembourg, indicating they come from native or at least $2^{\text {nd }}$ generation immigrant families. This is also reflected by their first language, as each year at least $63 \%$ of applicants speak Luxembourgish at home. Both the 
educational level and occupational status of the applicants' parents show that applicants come from a wide variety of socio-economic backgrounds.

Although there are fluctuations in demographic characteristics between years, no clear trends are observable. Therefore, we considered the sample as a whole to investigate to what extent applicants' demographic characteristics affected the admission process.

Chi-square analyses were conducted to investigate to what extent demographic characteristics were related to each other. As would be expected, results showed significant associations between country of birth and first language, $\chi^{2}(1, N=1,442)=162.58, p<0.001$, whereby applicants born in Luxembourg more often spoke Luxembourgish as their $1^{\text {st }}$ language. Similarly, parent educational attainment was related to their occupation, $\chi^{2}(1, N=1,419)=$ 237.14, $p<0.001$, such that parents completing higher forms of tertiary education also were more likely to have professional or managerial positions. Finally, the indicators of migration background were related to indicators of socio-economic status, such that applicants who were born in Luxembourg and with Luxembourgish as their first language more often had parents that completed higher levels of education $\left(\chi^{2}(3, N=1,433)=\right.$ $12.35, p<0.001$ and $\chi^{2}(3, N=1,433)=72.70, p<0.001$, respectively) and hold higher professional positions $\left(\chi^{2}(1, N=1,426)=13.20, p<\right.$ 0.001 and $\chi^{2}(1, N=1,426)=144.11, p<0.001$, respectively).

Of the 1,442 registered applicants, 441 (30.6\%) failed to show up for the entry exam. A logistic regression analysis revealed that demographic variables are not significantly associated with who turns up or not at the exam $\left(\chi^{2}(5, N=1,426)=2.17, p=0.83\right.$; McFadden $R^{2}=0.001^{2}$ ). In other words, not turning up for the exam was not related to the applicants' gender, place of birth, first language, or their parents' educational or occupational status.

From the 1,001 applicants who sat the entry exam, 434 (53\%) were (conditionally) admitted into the teacher education program. To investigate a potential bias within the admission process we conducted a logistic regression analysis whereby we considered the applicants' gender as well as migration background and socioeconomic status. Country of birth (Luxembourg vs. elsewhere) and first language (Luxembourgish or Luxembourgish bilingual vs. other) were used as indicators of migration whereas parents' education (secondary education only vs. tertiary education) and occupation (unskilled vs. skilled) were included as indicators of socio-economic status. The test of the full model against a constant only model was statistically significant, indicating that the predictors as a set reliably distinguished between successful and unsuccessful applicants $\left(\chi^{2}(5, N=989)=127.52, p<0.001\right)$. The relationship between prediction and grouping was weak (McFadden $R^{2}=0.09$ ), however the Wald test demonstrated that gender, first language and parental education significantly contributed to the association, whereas country of birth and parental occupation did not (see Table 2). More specifically, results indicate that male applicants, applicants with Luxembourgish as their first language and applicants with

${ }^{2}$ Within the logistic regression models, the McFadden $R^{2}$ can be interpreted as the approximate variance in the outcome accounted for by the predictor variables. parents attaining higher educational levels have significantly more chance to be successful in the admission process.

Finally, we considered possible advantages accrued to certain groups of applicants by comparing the demographic constellation of successful candidates to the diversity of registered applicants (see Table 3). Differences in the constellation of the two groups (registered applicants vs. admitted students), indicate that the diversity of the cohort is affected. Although the gender distribution becomes more even (though still in favor of females), the diversity in terms of migration or socio-economic status reduces as the majority of the successful applicants seem to come from native (based on their first language) and more educated families, which is also reflected in the distribution of parents' occupational level.

\section{DISCUSSION}

Every year, large numbers of applicants register for the entry exam for the teacher education program in Luxembourg. Data presented in this paper show that although most applicants were born in Luxembourg, they come from diverse backgrounds in terms of migration and socio-economic status. More specifically, the distribution of demographic characteristics indicate that applicants represent the different layers and heterogeneity of Luxembourg society and demonstrate that the application process is open for everyone provided they hold a recognized secondary school leaving diploma. However, if we compare the demographic characteristics of the applicants with the national estimates for working-age adults in Luxembourg (STATEC, 2020c), it becomes clear that there is an over-representation of candidates from more privileged families. More specifically, national estimates of adults in skilled jobs in the years 2015-2019 ranges from $56-61 \%$, whereas for the registered candidates it ranges from $58-71 \%$. In addition, applicants with migration backgrounds mainly represented $2^{\text {nd }}$ and later generations of migrants. Relationships between indicators of migration background and socio-economic status further show that applicants with and without migration backgrounds come from families with different socio-economic backgrounds (migration background is associated with less privileged socio-economic status), which mirrors the situation in Luxembourgish society as a whole.

Considering data for five cohorts (2015-2019), the demographic characteristics of applicants vary slightly per year, most notably in terms of applicants' first language and their parents' educational attainment, although no real trend toward more diversification was observed. Results of a regression analysis show that some demographic characteristics increase the likelihood of being admitted to the teacher education program in Luxembourg. The advantage for applicants with Luxembourgish as their first language, who are 3.5 times more likely to be successful in the application process, may reflect the specific language requirements set by the Luxembourgish government to enter the teaching profession. These requirements are considered when setting the criteria for selection into the teacher education program (University of Luxembourg, 2020a). The focus on proficiency of all three of the country's official languages (Luxembourgish, French and German) may explain the fact that Luxembourgish is the first language of most applicants, 
TABLE 2 | Demographic characteristics as predictors of admission.

\begin{tabular}{|c|c|c|c|}
\hline & Odds ratio & Wald & $p$-value \\
\hline $\begin{array}{l}\text { Gender } \\
\text { Female vs. Male }\end{array}$ & 2.98 & 47.81 & 0.000 \\
\hline $\begin{array}{l}\text { Country of birth } \\
\text { Lux vs. other }\end{array}$ & 1.00 & 0.11 & 0.74 \\
\hline $\begin{array}{l}\text { First language } \\
\qquad \text { Lux/Lux bilingual vs. other }\end{array}$ & 0.34 & 35.72 & 0.000 \\
\hline $\begin{array}{l}\text { Highest parental education } \\
\text { Secondary education only vs. Tertiary education }\end{array}$ & 1.54 & 8.14 & 0.004 \\
\hline $\begin{array}{l}\text { Highest parental occupation } \\
\text { Unskilled vs. Skilled }\end{array}$ & 1.07 & 0.19 & 0.67 \\
\hline $\begin{array}{l}\text { Constant } \\
\text { McFadden } R^{2}=0.09\end{array}$ & 3.3 & 17.56 & 0.000 \\
\hline
\end{tabular}

Reference group: admitted to teacher education program.

TABLE 3 | Characteristics of registered applicants vs. admitted students into the teacher education program (2015-2019).

\begin{tabular}{|c|c|c|}
\hline & Registered applicants & Admitted students \\
\hline & $N=1,442$ & $N=434$ \\
\hline \multicolumn{3}{|l|}{ Gender } \\
\hline Male & $26.6 \%$ & $37.6 \%$ \\
\hline Female & $73.4 \%$ & $62.4 \%$ \\
\hline \multicolumn{3}{|l|}{ Migration background indicators } \\
\hline \multicolumn{3}{|l|}{ Country of birth } \\
\hline Luxembourg & $93.3 \%$ & $94.5 \%$ \\
\hline Elsewhere in europe & $3.4 \%$ & $2.1 \%$ \\
\hline Balkan & $1.3 \%$ & $1.4 \%$ \\
\hline Elsewhere outside europe & $2.0 \%$ & $2.1 \%$ \\
\hline \multicolumn{3}{|l|}{ Language spoken at home } \\
\hline Luxembourgish & $70.7 \%$ & $83.2 \%$ \\
\hline Luxembourgish Bilingual & $1.9 \%$ & $1.8 \%$ \\
\hline Other european language & $21.1 \%$ & $11.3 \%$ \\
\hline Balkan language & $5.1 \%$ & $3.2 \%$ \\
\hline Other non-European language & $1.2 \%$ & $0.5 \%$ \\
\hline \multicolumn{3}{|l|}{ Socio-economic indicators } \\
\hline \multicolumn{3}{|l|}{ Highest parental education } \\
\hline Secondary education only & $43.4 \%$ & $38.2 \%$ \\
\hline Some form of tertiary education & $56.6 \%$ & $61.8 \%$ \\
\hline \multicolumn{3}{|l|}{ Highest parental occupation } \\
\hline Unskilled & $35.6 \%$ & $27.8 \%$ \\
\hline Skilled & $64.4 \%$ & $72.2 \%$ \\
\hline
\end{tabular}

whereby the selection process further enhances the skewness in the first language distribution. As such, the focus on proficiency of the native language(s) may hinder the diversification of the teacher profession (secondary effects - see Boudon, 1974) as they result in disadvantages for students with migration backgrounds, especially those that did not grow up in Luxembourg and thus have not been exposed to or mastered the various languages. This may explain why most applicants with migration backgrounds were born in Luxembourg ( $2^{\text {nd }}$ or later generations of migrants), as participation in the Luxembourgish educational system would have allowed them to acquire proficiency in the three mandatory languages. Nevertheless, as the language spoken at home differs from the language of instruction (i.e., German and French), they may have experienced disadvantages in the educational system, especially when their parents have low levels of educational attainment and were less able to provide educational support or guidance (Alba and Foner, 2016). These disadvantages may accumulate over time, especially when proficiency of the native language in part determines access to tertiary education, such as the teacher education program. The advantage of Luxembourgish as a first language may also reflect general conceptions that only the majority group attain the required language proficiency level (see Döll and Knappik, 2015). Moreover, the focus on proficiency in multiple languages, most notably Luxembourgish and French ("elite bilingualism," Horner and Weber, 2008, p. 72) in legislation and policies has historically created certain advantages for Luxembourgish nationals in terms of social and economic opportunity, whereby especially proficiency in Luxembourgish serves "as a gate keeping device with regard to civil service positions” (Horner and Weber, 2008, p. 119). 
Parents' educational attainment level also affects the applicants' chances of success and on average $62 \%$ of successful applicants come from families where at least one parent completed the higher forms of tertiary education. These data are comparable to data from other countries (Chesters and Watson, 2013; Edelmann et al., 2015) and parental educational attainment is generally regarded as one of the main predictors of participation in higher education (European Commission, EACEA and Eurydice, 2018b). As such, these findings may reflect a pattern of social reproduction (see Bourdieu, 1973). At the same time, it should be noted that over the last five years almost $40 \%$ of successful applicants came from families where neither parent completed any form of tertiary education, and the admission to the teacher education program will provide these applicants with opportunities to reach higher educational attainment levels than their parents and to access higher status occupations and hence upward social mobility (Morgan, 2006).

The gender distribution of applicants reflect that generally more females enter the teaching profession than males. It is however interesting to note that males are three times more likely to be accepted into the teacher education program than females. This then becomes visible in the distribution of successful candidates, although females are still over-represented (2:3 male-female ratio). This apparent advantage among males will contribute to the future diversification of the teacher profession, even though teachers in Luxembourg are currently still predominantly female (OECD, 2020), especially in (pre)primary education (MENJE, 2017). Nevertheless, the advantage for male candidates is likely a combination of differences in preparedness and self-selection. The teaching profession, especially at the primary school level, is outside the 'traditional' male-dominated professions and thus would seem to call to the more committed and prepared. For women the opposite may be true as teaching at the fundamental school level may be understood as a readily available career opportunity which requires no special commitment or preparation and thus larger number of women apply. In effect then, what we find as a statistical 'advantage' could merely reflect constrained variance within the pool of male vs. female candidates.

It should be noted that the admission process aims to select candidates based on merit (i.e., performance and motivation) regardless of applicants' demographic characteristics. Typically, the teaching program aims to identify candidates with a 'generalist' profile, that is to say, candidates who can successfully, demonstrate high proficiency in the three main languages and math and science (University of Luxembourg, 2020a). The focus on language competence is directly related to the legislative requirement of proficiency in the three official languages of Luxembourg to be eligible for civil service positions such as the teaching profession. Such requirement reflects a practice in society, rather than the educational system per se or the admission process in particular, that may create different opportunities for people from different backgrounds and hence may facilitate social reproduction rather than social mobility. This may be especially true for first generation migrants, although second and later generations may also experience some disadvantages as they speak languages at home that are different from the language of the host country and especially the language of instruction at school (Alba and Foner, 2016). In addition, Luxembourg's academic tracking system constrains students into specialized academic paths from the age of 12 (Lenz and Heinz, 2018), which in turn affects the number of qualified candidates and demographic constellation of cohorts. More specifically, research has shown that student with immigrant backgrounds are under-represented at higher tracks, which in turn affects their educational opportunities (i.e., access to University). Again, this systemic factor may facilitate social reproduction, especially for first generation migrants, but again is inherent of the educational system and not the admission process of the teacher education program. Such systemic influences may lead to a cumulative advantage for the majority group (DiPrete and Eirich, 2006) whereby (dis) advantages increase over time. Observed educational inequalities in primary and secondary education (OECD, 2018) in turn reduce opportunities for students with migration backgrounds in further education and careers (Schalke et al., 2013). This may explain why, even when the application process is merit based, current results show that demographic characteristics can explain 9\% of variance in success in the application process. Future research may however consider the impact of demographic characteristics after controlling for variations in key selection criteria to further our understanding of factors contributing to (dis)advantages for certain groups of applicants in the application process to ultimately facilitate social mobility and reduce societal inequalities.

Given the systemic influences diversification of the pre-and in-service teacher workforce remains a challenge and will require time. It is therefore important that teacher (continuing) education programs incorporate multiculturalism, not only to prepare teachers to support students with a variety of academic profiles and socio-demographic characteristic to reach their full potential, but also to bring about change in beliefs concerning the academic potential of students from minority groups (Hachfeld et al., 2015). Future research could then evaluate the individual and combined impact of diversification and multiculturalism on reducing educational inequalities.

Some limitations should be mentioned. As this study is based on secondary analysis of data, the socio-demographic background indicators only provide a limited insight in the applicants' migration backgrounds. For example, the country of birth may only be indicative of $1^{\text {st }}$ generation immigrants. First language may be a better indicator of migration backgrounds, especially as speaking Luxembourgish may be considered an essential part of Luxembourgish or national identity (Horner and Weber, 2008). It is likely that especially $2^{\text {nd }}$ generation immigrant students still speak at home the language of their parents who were born outside of Luxembourg. However, although applicants' first language may reflect that (grand)parents were born outside Luxembourg, the data does not allow to distinguish between $2^{\text {nd }}$ and later generations. Second, we noticed a large number of registered applicants $(31 \%)$ did not show for the entry exam. This may reflect that prospective candidates did not pass their final secondary exams, especially as $52 \%$ of candidates that did not show up re-registered in the following year. However, as no further information is available we can merely speculate about this. 
Third, the study focused on the effect of demographic characteristics on the likelihood to be accepted in the teacher education program. However, acceptance into the program does not guarantee the successful completion of the bachelor degree. Previous research has indicated that students with migration backgrounds are more likely to break off their studies or dropout altogether (Bandorski and Karakaşoğlu, 2013; European Commission, EACEA and Eurydice, 2018b). Therefore, future research may consider not only the admission process but also the academic progression of applicants/students in relation to their demographic background.

\section{CONCLUSION}

This study regarded demographic constellations of five cohorts of applicants for admission into the teacher education program in Luxembourg and analyzed the extent to which the admission process may (dis)advantage certain groups. Results indicate that regardless of the diversification of society, diversity of prospective teachers is partly predicted by focus on proficiency in the country's native language. This creates disadvantages for candidates with immigrant backgrounds, especially $1^{\text {st }}$ and $2^{\text {nd }}$ generation families, and hence may facilitate social reproduction rather than enable social mobility. The focus on the native language also limits opportunity to diversify the teaching profession and the discrepancy between student and teacher heterogeneity will be maintained. The (dis)advantages for certain groups of (prospective) students may however be associated primarily with historically established practices in society, legislation or education (Apple, 2001), rather than the process of admission into the teacher education program. To enhance the diversity in the teaching profession it may be necessary to consider both diversification of entry routes into teacher education program and the reduction of inequalities within the educational system. Currently, entry into the teacher education program is based on a competitive entrance examination after obtaining the upper secondary leaving certificate, which may -unwittingly- advantage native students and students from more privileged backgrounds. To enhance diversity, access to the teacher education program for students with migration and less privileged backgrounds may be facilitated by providing bridging programmes or by offering specific (language) support in order to reach acquired proficiency levels (European Commission, EACEA and Eurydice, 2018b). The admission procedure at the University of Luxembourg has offered conditional admissions to candidates who were otherwise qualified in all domains except one. The teacher education program then offers remediation training and opportunities to improve the mastery of the specific subject matter before these students are allowed to graduate. Efforts should also be made to reduce inequalities within the educational system, for example by making the decisions concerning tracking as fair and accurate as possible (e.g., see Pitten Cate et al., 2016). In addition, it is vital to prepare students in the teacher education program to deal with student diversity, especially as approximately $50 \%$ of students in the Luxembourgish school system do not hold the Luxembourgish nationality (Lenz and Heinz, 2018). In this regard it is important to consider that the effective teaching of diverse groups not only requires pedagogical knowledge and skills (Kunter et al., 2013) but also a reflection on the value-added of diversity (e.g., Hachfeld et al., 2015). In addition, it would be important to reflect on beliefs concerning diversity and inclusion to overcome possible stereotype-based expectations concerning the academic proficiency of specific groups of students (e.g., Wang et al., 2018; Zhu et al., 2018). Hence, preparing prospective teachers for diversity could be one way to support students from minority backgrounds to attain higher levels of academic proficiency, enabling their access to tertiary education. As such, teacher education could play a pivotal role in "widening opportunities for access and completion [of higher education] for students from disadvantaged backgrounds" (European Commission, EACEA and Eurydice, 2018b, p. 153) and ultimately lead to diversification of the adult population in skilled jobs, such as the teacher profession. As such it may not be the admission process to the teacher education program that reinforces educational and societal inequalities by reducing opportunities for diversification and social mobility, but rather the content of the teacher education program and practices in the educational system (e.g., tracking). Striving toward more educational equality in primary and secondary education may ultimately lead to a more diverse sample of students who attends tertiary education in general and the teacher education program in particular. Reducing inequalities may ultimately facilitate reaching "the societal aspiration that the student body entering, participating in, and completing higher education [and as such the teacher education program] should reflect the diversity of our populations" (EACEA and Eurydice, 2010, p. 27).

\section{DATA AVAILABILITY STATEMENT}

The data analyzed in this study is subject to the following licenses/ restrictions: The data was collected as part of the application process. For this article the anonymized cohort data was used for secondary analyses. The dataset is not available for use outside the University department. Requests to access these datasets should be directed to salvador.rivas@uni.lu.

\section{ETHICS STATEMENT}

Ethical review and approval was not required for the study on human participants in accordance with the local legislation and institutional requirements. Data was collected as part of the application process, whereby participants gave written consent for their data to be used for administrative, quality assurance and monitoring processes. Written informed consent for participation was not required for the secondary analyses of these data (i.e., this specific study) in accordance with the national legislation and the institutional requirements.

\section{AUTHOR CONTRIBUTIONS}

IP-tC - Conceptualization; Formal analysis; Methodology; Writing: original draft and revisions SR - Conceptualization; Data curation; Formal analysis; Writing: review editing GB Data collection; Writing: review editing. 


\section{REFERENCES}

Akbaba, Y., Bräu, K., and Zimmer, M. (2013). "Erwartungen und Zuschreibungen: Eine Analyse und kritische Reflexion der bildungspolitischen Debatte zu Lehrer/innen mit Migrationshintergrund. [Expectations and Attributions: An analysis and critical reflection of the educational policy debate on teachers with migration backgrounds]," in Lehrerinnen und Lehrer mit Migrationshintergrund. Zur Relevanz eines Merkmals in Theorie, Empirie und Praxis. Editors K. Bräu, Y. Karakaşoğlu, and C. Rotter (Münster, Germany: Waxmann), 37-57.

Alba, R., and Foner, N. (2016). Integration's Challenges and Opportunities in the Wealthy West. J. Ethnic Migr. Stud. 42, 3-22. doi:10.1080/1369183X.2015.1083770

Apple, M. W. (2001). Comparing Neo-Liberal Projects and Inequality in Education. Comp. Edu. 37, 409-423. doi:10.1080/03050060120091229

Azzolini, D., and Barone, C. (2013). Do they Progress or Do They Lag behind? Educational Attainment of Immigrants' Children in Italy: The Role Played by Generational Status, Country of Origin and Social Class. Res. Soc. Stratif. Mobility 31, 82-96. doi:10.1016/j.rssm.2012.11.002

Bandorski, S., and Karakaşoğlu, Y. (2013). "Macht 'Migrationshintergrund' einen Unterschied? Studienmotivation, Ressourcen und Unterstützungsbedarf von Lehramtsstudierenden mit und ohne Migrationshintergrund. [Does migration background make a difference? Study motivation, ressources and support needs of preservice teachers with and without migration backgrounds]," in Lehrerinnen und Lehrer mit Migrationshintergrund. Zur Relevanz eines Merkmals in Theorie, Empirie und Praxis. Editors K. Bräu, V. B. Georgi, Y. Karakaşoğlu, and C. Rotter (Münster, Germany: Waxmann), 133-155.

Banks, J. A. (2004). "Multicultural Education. Historical Development, Dimensions, and Practice," in Handbook of Research on Multicultural Education. Editors J. A. Banks and C. A. McGee Banks. 2nd ed. (San Francisco, CA: Wiley), 3-29.

Baumert, J., and Schümer, G. (2002). "Familiäre Lebensverhältnisse, Bildungsbeteiligung und Kompetenzerwerb im nationalen Vergleich," in PISA 2000 - Die Länder der Bundesrepublik Deutschland im Vergleich (Wiesbaden, Germany: VS Verlag für Sozialwissenschaften), 159-202. doi:10.1007/978-3-663-11042-2_6

Boehm, B., Ugen, S., Fischbach, A., Keller, U., and Lorphelin, D. (2016). PISA 2015 Nationaler Bericht Luxemburg. [PISA 2015 National Report Luxembourg.]. Luxembourg: MENJE and University of Luxembourg.

Boudon, R. (1974). Education, Opportunity and Social Inequality: Changing Prospects in Western Society. New York, NY: Wiley.

Bourdieu, P. (1973). "Cultural Reproduction and Social Reproduction," in Knowledge, Education and Cultural Change. Editor R. Brown (London, United Kingdom: Tavistock), 71-112.

Bressler, C., and Rotter, C. (2017). The Relevance of a Migration Background to the Professional Identity of Teachers. Ijhe 6, 239. doi:10.5430/ijhe.v6n1p239

Busana, G., Poncelet, D., Reiff, A., and Rivas, S. (in press). "Luxembourg's Fundamental School Teacher Training Programme: A Decade of Admission at the BScE," in Nationaler Bildungsbericht Luxemburg 2021. Editors LUCET and SCRIPT (Esch-sur-Alzette: University of Luxembourg (LUCET) and SCRIPT).

Chesters, J., and Watson, L. (2013). Understanding the Persistence of Inequality in Higher Education: Evidence from Australia. J. Edu. Pol. 28, 198-215. doi:10. 1080/02680939.2012.694481

DiPrete, T. A., and Eirich, G. M. (2006). Cumulative Advantage as a Mechanism for Inequality: A Review of Theoretical and Empirical Developments. Annu. Rev. Sociol. 32, 271-297. doi:10.1146/annurev.soc.32.061604.123127

Döll, M., and Knappik, M. (2015). Institutional Mechanisms of Inclusion and Exclusion in Austrian Pre-Service Teacher Education. Tertium Comparationis: J. Für Int. Interkulturell Vergleichende Erziehungswissenschaft 2, 185-204.

EACEA and Eurydice (2010). Focus on Higher Education in Europe 2010: The Impact of the Bologna Process. Brussels, Belgium: Publication office. doi:10. $2797 / 38158$

Edelmann, D., Bischoff, S., Beck, M., and Meier, A. (2015). More Studenst with Migration Backgrounds at University of Teacher Education. Theoretical Reflections and Empirical Insights on Potential Aspects and Challenges from the Perspectives of Pre-service Teachers and Lecturers. Tertium Comparationis: J. Für Int. Interkulturell Vergleichende Erziehungswissenschaft 2, 205-224.
Edelmann, D. (2013). "Lehrkräfte mit Migrationshintergrund - Ein Potenzial pädagogischer Professionalität im Umgamg mit der migrationsbedingter Heterogenität. [Teachers with migration backgrounds - A potential for educational professionalism in dealing with migration-related heterogeneity]," in Lehrerinnen und Lehrer mit Migrationshintergrund. Zur Relevanz eines Merkmals in Theorie, Empirie und Praxis. Editors K. Bräu, V. B. Georgi, Y. Karakaşoğlu, and C. Rotter (Münster, Germany: Waxmann), 197-209.

European Commission, EACEA and Eurydice (2018a). "Teaching Careers in Europe: Access, Progression and Support-Eurydice Report," in Education and Training. (Luxembourg: European Commission). doi:10.2797/309510

European Commission, EACEA and Eurodice (2018b). The European Higher Education Area in 2018: Bologna Process Implementation Report. Luxembourg: Publication office of the European Union. doi:10.2797/63509

Eurybase (2010). Organisation of the Education System in Luxembourg 2009/2010. Brussels, Belgium: European Commission.

Fine-Davis, M., and Faas, D. (2014). Equality and Diversity in the Classroom: A Comparison of Students' and Teachers' Attitudes in Six European Countries. Soc. Indic Res. 119, 1319-1334. doi:10.1007/s11205-013-0547-9

Fischbach, F., Ugen, S., and Martin, R. (2016). “Travail et éthicité démocratique," in PISA 2015 - Nationaler Bericht Luxemburg. Editors SCRIPT and LUCET (Luxembourg: MENJE), Vol. 36, 13-19. doi:10.3917/trav.036.0013

Georgi, V. B. (2013). "Empirische Forschung zu Lehrenden mit Migrationshintergrund, minority teachers and teachers of color. [Empirical research concerning teachers with migration backgrounds, minority teachers and teachers of color]," in Lehrerinnen und Lehrer mit Migrationshintergrund. Zur Relevanz eines Merkmals in Theorie, Empirie und Praxis. Editors K. Bräu, V. B. Georgi, Y. Karakaşoğlu, and C. Rotter (Münster, Germany: Waxmann), 85-103.

Geven, S. A. J., Batruch, A. H., and Van De Werfhorst, H. G. (2018). Inequality in Teacher Judgements, Expectations and Track Recommendations : A Review Study Amsterdam, Netherlands: University of Amsterdam.

Hachfeld, A., Hahn, A., Schroeder, S., Anders, Y., and Kunter, M. (2015). Should Teachers be Colorblind? How Multicultural and Egalitarian Beliefs Differentially Relate to Aspects of Teachers' Professional Competence for Teaching in Diverse Classrooms. Teach. Teach. Edu. 48, 44-55. doi:10.1016/j.tate.2015.02.001

Hachfeld, A., Schroeder, S., Anders, Y., Hahn, A., and Kunter, M. (2012). Multikulturelle Überzeugungen. Z. für Pädagogische Psychol. 26, 101-120. doi:10.1024/1010-0652/a000064

Hadjar, A., Fischbach, A., and Backes, S. (2018). "Bildungsungleichheiten im luxemburgischen Sekundarschulsystem aus zeitlicher Perspektive. [Educational inequalities in the Luxembourg secondary school system from a time prespective]," in Nationaler Bildungsbericht Luxemburg 2018. Editors LUCET and SCRIPT (Esch-sur-Alzette: University of Luxembourg, LUCET and MENJE/SCRIPT), 59-83.

Hadjar, A., and Gross, C. (2016). "Education Systems and Inequalities," in Education Systems and Inequalities: International Comparisons. Editors A. Hadjar and C. Gross (Bristol, United Kingdom: Policy Press), 1-10. doi:10.1332/policypress/9781447326106.003.0001

Hillmert, S. (2013). Links between Immigration and Social Inequality in Education: A Comparison Among Five European Countries. Res. Soc. Stratif. Mob. 32, 7-23. doi:10.1016/j.rssm.2013.02.002

Horner, K., and Weber, J. J. (2008). The Language Situation in Luxembourg1. Curr. Issues Lang. Plann. 9, 69-128. doi:10.2167/cilp130.0

Ingersoll, R. M., and May, H. (2011). The Minority Teacher Shortage: Fact or Fable? Phi Delta Kappan 93, 62-65. doi:10.1177/003172171109300111

Kelle, U., and Kluge, S. (2010). Vom einzellfall zum Typos. Fallvergleiche und Fallkontrastierung in der qualitativen Sozialforschung. [From individual cases to types. Case comparisons and contrasting cases in qualitative social research.]. 2nd edn. Wiesbaden, Germany: Verlag für Sozialwissenschaften.

Kunter, M., Klusmann, U., Baumert, J., Richter, D., Voss, T., and Hachfeld, A. (2013). Professional Competence of Teachers: Effects on Instructional Quality and Student Development. J. Educ. Psychol. 105, 805-820. doi:10.1037/a0032583

Lenz, T., and Heinz, A. (2018). "Das Luxemburgische Schulsystem: Einblicke und Trends. [The Luxembourgish school system: Insights and trends]," in Nationaler Bildungsbericht Luxemburg 2018. Editors LUCET and SCRIPT (Esch-sur-Alzette: University of Luxembourg (LUCET) and SCRIPT), 22-34. Luthra, R. R., and Soehl, T. (2015). From Parent to Child? Transmission of Educational Attainment within Immigrant Families: Methodological Considerations. Demography 52, 543-567. doi:10.1007/s13524-015-0376-3 
Magaldi, D., Conway, T., and Trub, L. (2018). "I am Here for a Reason": Minority Teachers Bridging Many Divides in Urban Education. Race Ethn. Edu. 21, 306-318. doi:10.1080/13613324.2016.1248822

Massey, S., Cameron, A., Ouellette, S., and Fine, M. (1998). Qualitative Approaches to the Study of Thriving: What Can Be Learned? J. Soc. Issues 54, 337-355. doi:10.1111/j.1540-4560.1998.tb01222.x

MENJE (2017). The Key Figures of the National Education: Statitistics and Indicators 2015/2016. Luxembourg: Imprimerie Centrale.

Ministere d Etat (2020). Plan général du code de l'éducation nationale. [General plan of the national education code]. Mémorial A, No 771 du 16 septembre 2020. Available at: http://legilux.public.lu/eli/etat/leg/code/education_nationale/20200915 (Accessed October 21, 2020).

Morgan, S. L. (2006). "Past Themes and Future Prospects for Reserach on Social and Economic Mobilty," in Mobility and Inequality. Editors S. L. Morgan, D. B. Grusky, and G. S. Fileds (Stanford, CA: Stanford University Press), 3-20.

Oakes, J. (2005). Keeping Track: How Schools Structure Inequality. 2nd edn. New Haven, CT: Yale University Press.

OECD (2020). Distribution of Teachers by Age and Gender. https://stats.oecd.org/ Index.aspx?DataSetCode=EAG_PERS_SHARE_AGE.

OECD (2018). Equity in Education: Breaking Down Barriers to Social Mobility (PISA). Paris, France: OECD Publishing. doi:10.1787/9789264073234-en

OECD (2010). PISA 2009 Results: Overcoming Social Background - Equity in Learning Opportunities and Outcomes (Vol II). Paris, France: OECD Publishing. doi:10.1787/9789264091504-en

OECD (2016). PISA 2015 Results in Focus. Paris, France: OECD Publishing. doi:10. 1787/9789264266490-en

OECD (2019). PISA 2018 Results (Volume I): What Students Know and Can do. Paris, France: OECD Publishing. doi:10.1787/5f07c754-en

Pit-ten Cate, I. M., Krolak-Schwerdt, S., and Glock, S. (2016). Accuracy of Teachers' Tracking Decisions: Short- and Long-Term Effects of Accountability. Eur. J. Psychol. Educ. 31, 225-243. doi:10.1007/s10212-015-0259-4

Rotter, C. (2012). Lehrkräfte mit Migrationshintergrund. Individuelle Umgangsweisen mit bildungspolitischen Erwartungen. [Teachers with migration backgrounds. Individual ways of dealing with educational-political expectatons]. Z. Für Pädagogik 58, 204-222.

Schalke, D., Brunner, M., Geiser, C., Preckel, F., Keller, U., Spengler, M., et al. (2013). Stability and Change in Intelligence from Age 12 to Age 52: Results from the Luxembourg MAGRIP Study. Dev. Psychol. 49, 1529-1543. doi:10.1037/ a0030623

STATEC (2020a). 626000 habitants au ler janvier 2020. [626,000 inhabitants on January 1, 2020]. Luxembourg: STATEC. Available at: https://statistiques.public. $\mathrm{lu} /$ fr/actualites/population/population/2020/04/20200401/20200401.pdf.
STATEC (2020c). European Labour Force Survey [data set]. Available at: https://ec. europa.eu/eurostat/web/lfs/data/database.

STATEC (2020b). Le Luxembourg, Terre d ' Immigration [Luxembourg, Land of Immigration]. Luxembourg: STATEC, 1-5. Available at: https://statistiques. public.lu/catalogue-publications/regards/2020/PDF-05-2020.pdf.

Su, Z. (1997). Teaching as a Profession and as a Career: Minority Candidates' Perspectives. Teach. Teach. Edu. 13, 325-340. doi:10.1016/S0742-051X(96)00021-2

United Nations Economic Comission for Europe (2006). Conference of European Statisticians Recommendations for the 2010 Censuses of Population and Housing. Available at: http://www.unece.org/fileadmin/DAM/stats/publications/CES 2010_Census_Recommendations_English.pdf.

University of Luxembourg (2020a). Admission 2020. Available at: https://bsce. assessment.lu/admission/welcomePage.html (Accessed October 27, 2020).

University of Luxembourg (2020b). Bachelor en Sciences de l'Éducation. Available at: https://wwwen.uni.lu/studies/fhse/bachelor_en_sciences_de_l_education/ admission (Accessed October 27, 2020).

Van de Werfhorst, H. G., and Mijs, J. J. B. (2010). Achievement Inequality and the Institutional Structure of Educational Systems: A Comparative Perspective. Annu. Rev. Sociol. 36, 407-428. doi:10.1146/annurev.soc.012809.102538

Wang, S., Rubie-Davies, C. M., and Meissel, K. (2018). A Systematic Review of the Teacher Expectation Literature over the Past 30 Years. Educ. Res. Eval. 24 (3-5), 124-179. doi:10.1080/13803611.2018.1548798

Waters, M. C., Heath, A., Tran, V. C., and Boliver, V. (2013). "Second-Generation Attainment and Inequality," in The Children of Immigrants at School: A Comparative Look at Integration in the United States and Western Europe. Editors R. Alba and J. Holdaway (New York, NY: NYU Press), 120-159. doi:10. 18574/nyu/9780814760949.003.0004

Zhu, M., Urhahne, D., and Rubie-Davies, C. M. (2018). The Longitudinal Effects of Teacher Judgement and Different Teacher Treatment on Students' Academic Outcomes. Educ. Psychol. 38, 648-668. doi:10.1080/01443410.2017.1412399

Conflict of Interest: The authors declare that the research was conducted in the absence of any commercial or financial relationships that could be construed as a potential conflict of interest.

Copyright (C) 2021 Pit-ten Cate, Rivas and Busana. This is an open-access article distributed under the terms of the Creative Commons Attribution License (CC BY). The use, distribution or reproduction in other forums is permitted, provided the original author(s) and the copyright owner(s) are credited and that the original publication in this journal is cited, in accordance with accepted academic practice. No use, distribution or reproduction is permitted which does not comply with these terms. 